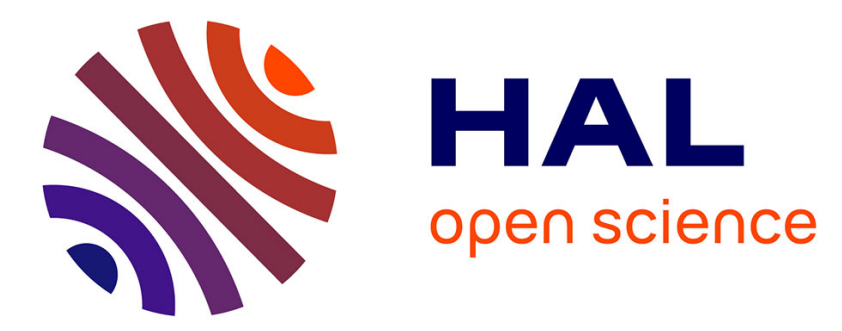

\title{
Effect of thermal residual stresses on the strength for both alumina/Ni/alumina and alumina/ $\mathrm{Ni} /$ nickel alloy bimaterials
}

Lamine Hattali, Stéphane Valette, Francois Ropital, Nadir Mesrati, Daniel Tréheux

\section{To cite this version:}

Lamine Hattali, Stéphane Valette, Francois Ropital, Nadir Mesrati, Daniel Tréheux. Effect of thermal residual stresses on the strength for both alumina/Ni/alumina and alumina/Ni/nickel alloy bimaterials. Journal of Materials Science, 2009, 44, pp.3198-3210. 10.1007/s10853-009-3426-7 . hal-00658202

\section{HAL Id: hal-00658202 https://hal.science/hal-00658202}

Submitted on 10 Jan 2012

HAL is a multi-disciplinary open access archive for the deposit and dissemination of scientific research documents, whether they are published or not. The documents may come from teaching and research institutions in France or abroad, or from public or private research centers.
L'archive ouverte pluridisciplinaire HAL, est destinée au dépôt et à la diffusion de documents scientifiques de niveau recherche, publiés ou non, émanant des établissements d'enseignement et de recherche français ou étrangers, des laboratoires publics ou privés. 


\title{
Effect of thermal residual stresses on the strength for both alumina/Ni/alumina and alumina/Ni/nickel alloy bimaterials
}

\author{
M. L. Hattali $\cdot$ S. Valette $\cdot$ F. Ropital $\cdot$ \\ N. Mesrati $\cdot$ D. Tréheux
}

Received: 18 September 2008/ Accepted: 17 March 2009/Published online: 7 April 2009

(C) Springer Science+Business Media, LLC 2009

\begin{abstract}
This paper describes some technical limitations encountered in joining ceramics-ceramics or ceramicsmetals, and how, to some extent, they have been practically overcome. The effect of the residual stresses on the strength of joints fabricated between alumina-alumina or alumina and the nickel base alloy HAYNES ${ }^{\circledR} 214^{\mathrm{TM}}$ using a solid-state bonding technique with $\mathrm{Ni}$ interlayer was studied. Finite element analyses (FEA) for the elasticplastic and elastic-plastic-creep behavior have also been used to better design the joints and to predict their performance. It was found that the residual stresses caused by the thermal expansion mismatch between alumina $\left(\mathrm{Al}_{2} \mathrm{O}_{3}\right)$ and the Ni-based superalloy $\left(\mathrm{HAYNES}^{\circledR} 214^{\mathrm{TM}}\right.$ ) have severely deteriorated the joints compared to $\mathrm{Al}_{2} \mathrm{O}_{3}-\mathrm{Al}_{2} \mathrm{O}_{3}$ joint fabricated with the same solid-state bonding parameters. The high residual stresses zones obtained through the FEA simulation fitted well with the fractographic observations of the $\mathrm{Al}_{2} \mathrm{O}_{3} / \mathrm{Ni} / \mathrm{HAYNES}^{\circledR} 214^{\mathrm{TM}}$ joints. Also, in order to use the joint material as a structural material, the study about the effect of geometrical parameters has been performed. Optimal geometries have been determined.
\end{abstract}

\section{Introduction}

Ceramics are being used increasingly in engineering applications to provide advances in components such as gas turbines, turbo exchangers, and high temperature reactors [1]. But, even though ceramic materials are excellent due to their light weight, wear resistance, or high heat resistance, it is sometimes difficult to use ceramic materials as general structural materials because they have some fatal weakness in impact resistance, toughness, or during manufacturing process. However, in order to be used more effectively, ceramics can be joined to metals. Joining ceramics to metals can allow their use:

- in complex-shaped components which are difficult to produce as monolithic bodies;

- as a cladding to provide resistance to wear, erosion, corrosion, or heat insulation; and

- at high temperature, in composite structures which are too highly stressed to be made totally in ceramic materials.

Various ceramic-to-metal joining techniques, utilizing or not a liquid phase, have been developed and improved over the past 60 years, among which solid-state diffusion bonding [2-7] and reactive metal brazing [2, 5, 7-10]. Both processes are widely used, especially because strong and gas proof bonds can be obtained. However, for brazing, a number of difficulties, like the poor wetting characteristics of the ceramic by the molten braze alloy, have to be solved. Techniques like Mo-Mn metallization [11] or the use of active brazing alloys [9, 12] are examples of the evolution on the brazing process that have been applied to ceramic materials. For a solid-state diffusion bonding, for which the wettability does not intervene, the adhesion is attributed to two main mechanisms: (i) the plastic deformation of the 
surface asperities [13]; and (ii) the closure of the voids by diffusive or evaporation condensation mass transport processes. Therefore, the diffusion bonding process is made easier by the use of a soft metallic interlayer which will allow the occurrence of the first mechanism (i).

A significant amount of fundamental information on Metal/Ceramic (M/C) bonding have been obtained, for example, on the $\mathrm{Al}_{2} \mathrm{O}_{3} / \mathrm{Ni} / \mathrm{Al}_{2} \mathrm{O}_{3}[3,14,15], \mathrm{Al}_{2} \mathrm{O}_{3} / \mathrm{Ag} /$ $\mathrm{Al}_{2} \mathrm{O}_{3}$ [4], and $\mathrm{Al}_{2} \mathrm{O}_{3} / \mathrm{Nb} / \mathrm{Al}_{2} \mathrm{O}_{3}[16,17]$ systems. All these works have pointed out that the bonding mechanisms are sensitive to the process parameters such as the temperature and the atmosphere. Other important parameters that control the process kinetic are the time and the externally applied static pressure, the latter providing the good physical contact from which an efficient mass transport across the interface depends. Chemical reactivity at the interface is also a fundamental requirement for effective $\mathrm{M} / \mathrm{C}$ bonding. A number of studies on metal/ceramic interfaces have shown that both chemical and mechanical bonding determine the strength of the interface [18]. However, chemical bonding takes a dominant role in metal-ceramic interfacial bonding and is necessary for strong adhesion. The reactivity of $\mathrm{Al}_{2} \mathrm{O}_{3}$ with pure metals has been studied by several authors, mostly directed to metals such as $\mathrm{Fe}, \mathrm{Cu}, \mathrm{Ti}, \mathrm{Ni}$, and $\mathrm{Nb}$. The bonding between $\mathrm{Al}_{2} \mathrm{O}_{3}$ and Ti usually occurs with the formation of intermetallic phases $[9,19]$. As for $\mathrm{Fe}$, the bonding of $\mathrm{Ni}$ or $\mathrm{Cu}$ with $\mathrm{Al}_{2} \mathrm{O}_{3}$ is usually associated with the formation of complex oxides such as $\mathrm{NiAl}_{2} \mathrm{O}_{4}[3,20,21]$ and $\mathrm{CuAl}_{2} \mathrm{O}_{4}$ [22] or $\mathrm{CuAlO}_{2}$ [23]. The formation of intermediate phases (interphases) is one of the several chemical reactions occurring at metal/ceramic interfaces. The typical scale of this reaction is on the order $1 \mu \mathrm{m}$ [20] or more [24]. Trumble and Rühle [20] studied the interfacial reaction at nickel-alumina interfaces, and concluded that the formation of nickel aluminate spinel, $\mathrm{NiAl}_{2} \mathrm{O}_{4}$, at the interface occurs when the oxygen activity of oxygen-containing nickel is above a threshold. Some studies claim that spinel formation at the interface leads to an increase in the interfacial strength [25-27], whereas others conclude that it weakens the interface [28, 29]. However, no quantitative study of this effect on nickel-alumina interfacial fracture toughness has been performed. Once the bonding is obtained, the strength of the joint is primarily dependent on the residual stresses at the interface. In general, ceramics and metals are joined at high temperature [7]. The residual stresses of the joint will grow during the cooling process by the plastic constraint of both materials due to the difference of thermal expansion between ceramics and metals. Consequently, the tensile residual stress occurring in ceramic considerably lowers the fracture strength of joint material [10].
Finite element (FE) modeling has been applied not only to quantify the residual stress, but also to describe the stress field. FEA resulted in a satisfactory description of the residual stresses in $\mathrm{M} / \mathrm{C}$ joints, mainly when the metallic components started to be modeled by an elasto-plastic behavior [30] instead of a pure elastic one [10]. However, the majority of the studies relates to symmetrical systems ceramic/metal/ceramic, without taking into account an elasto-plastic-creep model.

The aim of this research is to evaluate the problems encountered during the joining process between $\mathrm{Al}_{2} \mathrm{O}_{3}$ and $\mathrm{Al}_{2} \mathrm{O}_{3}$ or $\mathrm{Al}_{2} \mathrm{O}_{3}$ and the nickel base alloy HAYNES ${ }^{\circledR}$ $214^{\mathrm{TM}}$ by solid-state bonding technique using a $\mathrm{Ni}$ interlayer. After, bonding, the interface region between $\mathrm{Al}_{2} \mathrm{O}_{3}$ and the $\mathrm{Ni}$ interlayer were observed for both systems and analyzed by SEM/EDX and Grazing X-ray diffraction (GIXRD). Finally, the strength of the joints was measured by a shear testing method and the results were compared to the residual stresses estimated by FEA using elasto-plastic or elasto-plastic-creep models.

\section{Experimental procedure}

\section{Materials}

With an aim of technology transfer, all the materials used in this work, are of industrial origin. The compositions of the used materials are summarized below:

1. Nickel-(99.5\% purity; $200 \mu \mathrm{m}$ thick).

2. HAYNES $^{\circledR} 214^{\mathrm{TM}}-\mathrm{Ni}$-superalloy $(75 \% \mathrm{Ni}, 16 \% \mathrm{Cr}$, $4.5 \% \mathrm{Al}, 3 \% \mathrm{Fe})$.

3. Alumina AL23 (HP) ( $>99.7 \%$ purity).

4. Alumina A99 (S) (96\% purity).

Taking into account the importance of intergranular films present in ceramics, often announced in the metalceramic literature $[11,31]$, two type of polycrystalline alumina material were chosen: alumina A99 'standard,' designated in this study $(\mathrm{S})$, rich on impurities $\left(\mathrm{SiO}_{2}, \mathrm{MgO}\right.$, $\mathrm{CaO}$, and $\mathrm{Na}_{2} \mathrm{O}$ ), containing a significant vitreous intergranular phase and some crystalline phases (spinel, cordierite...). This type of alumina frequently is used in molybdenum oxide process. Alumina AL23 designated (HP) from UMICORE Marketing services contains the same impurity that A99 alumina, but with lower proportions. The nickel base alloy is HAYNES ${ }^{\circledR} 214^{\mathrm{TM}}$, which is used in technological applications at high temperatures and in severe chemical atmosphere (petrochemical...). Both base material blocks were cut into small pieces with the dimension of $15 \mathrm{~mm} \times 5 \mathrm{~mm} \times 4 \mathrm{~mm}$ for bonding and for shear test at room temperature. 
Prior to bonding, ceramics were polished using diamond pastes $(14-1 \mu \mathrm{m})$. The surfaces of metal interlayer and alloy were lightly polished with a silicon carbide abrasive paper in order to remove any oxidation layers. All surfaces were cleaned by immersion in acetone with ultrasonic agitation for $0.5 \mathrm{~h}$. After drying in hot air, the base material blocks and the interlayer foil were prepared as block/foil/ block sandwiched assembly, as shown in Fig. 1.

Finally the ceramic-metal-alloy 'sandwiches' were bonded with a diffusion process by hot-pressing the assembly during $1 \mathrm{~h}$ at $1150{ }^{\circ} \mathrm{C}$. The pressure of $16 \mathrm{MPa}$ is applied through a pneumatic piston [3, 4]. Heating speed was $150{ }^{\circ} \mathrm{C} / \mathrm{h}$ and cooling speed was $200{ }^{\circ} \mathrm{C} / \mathrm{h}$. The solidstate bonding was carried out in primary dynamic vacuum $\left(10^{-3} \mathrm{~Pa}\right)$ during all the temperature cycle. The experimental conditions were selected taking into account previous studies on alumina/Ni/alumina [3], alumina/Cu/ alumina [32], and alumina/Ag/alumina [4] systems.

The geometry of the samples was chosen taking into account the possibility of performing mechanical (shear test) and microstructural analysis (Fig. 2). The shear strength measurements were performed using an ADAMEL DY25 testing machine. The testing was carried out with a constant crosshead speed of $0.1 \mathrm{~mm} \mathrm{~min}^{-1}$ and the strength calculated by the fracture load was divided by the nominal area of the joint. Even if a pure shear stress field does not necessarily occur in this testing technique, it is, nonetheless, a suitable method for comparative evaluations. Finally, the interface microstructure was characterized by GIXRD, SEM, and quantitative EDS microanalysis.

\section{FEA analysis}

In order to determine the magnitude and distribution of the residual stresses in the joints, FEA was applied. Elastoplastic or elasto-plastic-creep regimes for the metal and Ni-based superalloy were adopted.

Continuum models have been used to compute the strains and stresses that develop in $\mathrm{Al}_{2} \mathrm{O}_{3} / \mathrm{Ni} / \mathrm{Al}_{2} \mathrm{O}_{3}$ or $\mathrm{Al}_{2} \mathrm{O}_{3} / \mathrm{Ni}$ / HAYNES $^{\circledR} 214$ samples during the cooling protocol from the assembly temperature $\left(1150{ }^{\circ} \mathrm{C}\right)$ to the room temperature $\left(25^{\circ} \mathrm{C}\right)$. A spatially uniform cooling (i.e., no thermal gradients) was assumed and time-dependent material proprieties (i.e., creep phenomena) were considered: only the

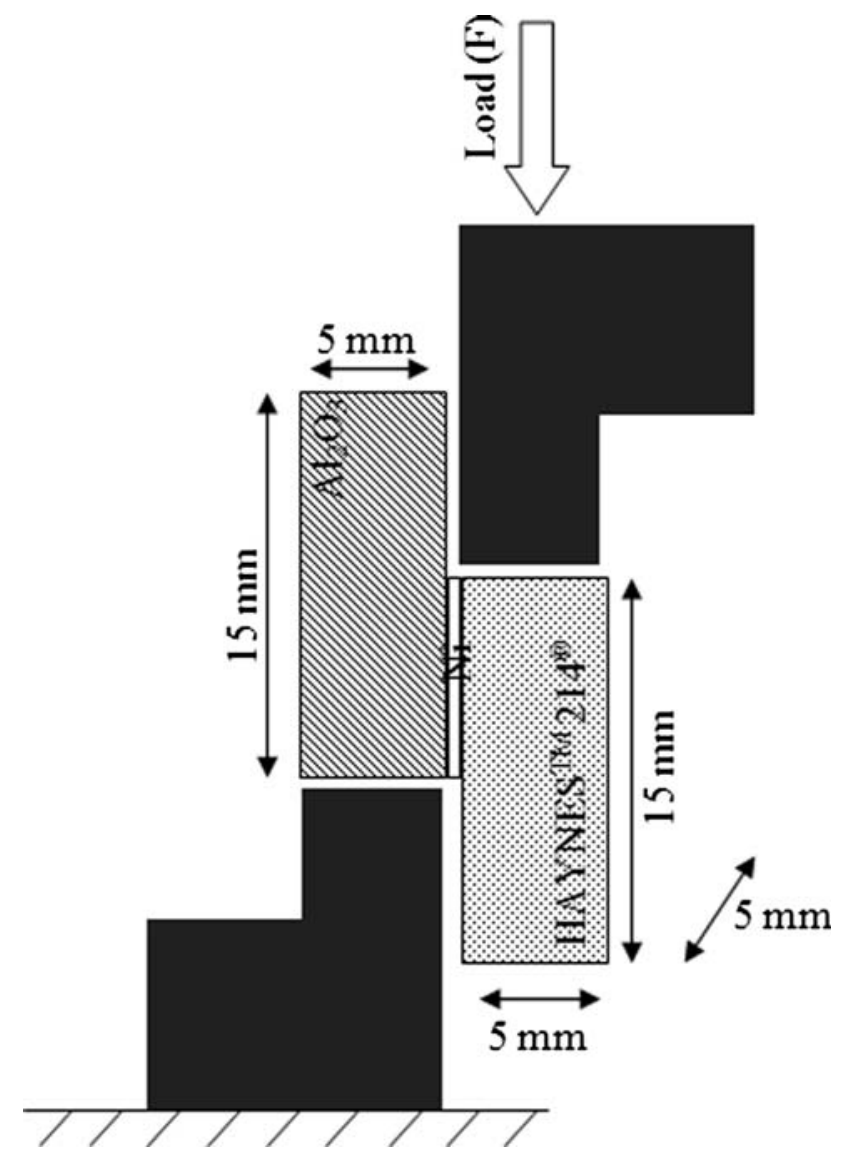

Fig. 2 Mechanical shear test and geometry adapted to the test

equations of stress equilibrium were solved. Dissimilar materials were assumed to be perfectly bonded at interfaces. Under such operating conditions, a plastic as well as a creep deformation was observed in nickel and HAYNES ${ }^{\circledR} 214$. Calculations were performed by using a finite element code ABAQUS 6.6.1 (Commercial FEA code) [33], assuming a two-dimensional geometry under a plane stress state.

The specimen geometry chosen for this model was a flat plate $10 \mathrm{~mm} \times 15 \mathrm{~mm}$ with different thicknesses of interlayer and materials. The mechanical properties for each material are shown in Tables 1,2, and 3. The most realistic (and the most computationally labor intensive) model is one that incorporates elasticity, plasticity, and creep. The effect of adding creep relaxation to the plastic calculation is then discussed and the progressive decrease in the
Fig. 1 Sample fabricated for the solid-state bonding, and thermal cycle

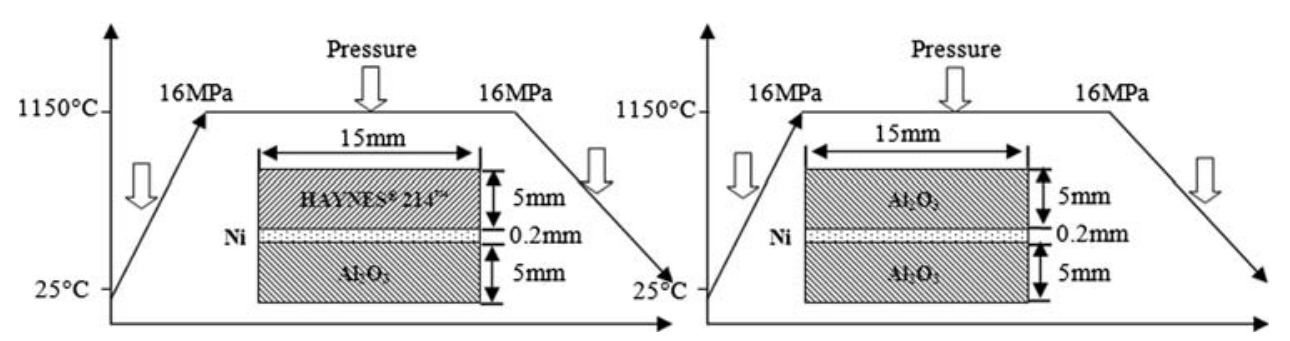


Table 1 Summary of nickel properties [40]

\begin{tabular}{|c|c|c|c|c|c|c|c|c|c|}
\hline$T(\mathrm{~K})$ & 298 & 398 & 598 & 798 & 998 & 1098 & 1198 & 1298 & 1398 \\
\hline$K(\mathrm{~W} / \mathrm{m} \mathrm{K})$ & 70.3 & 66.5 & 61.6 & 56.8 & 61.8 & 57.6 & 66.1 & 68.8 & N/a \\
\hline$C_{p}(\mathrm{~J} / \mathrm{Kg} \mathrm{K})$ & 456 & N/a & N/a & N/a & N/a & N/a & $\mathrm{N} / \mathrm{a}$ & $\mathrm{N} / \mathrm{a}$ & N/a \\
\hline$\alpha\left(\times 10^{-6} / \mathrm{K}\right)$ & 13.1 & 13.6 & 14.2 & 15.3 & 18.8 & 16.2 & 16.6 & 16.9 & 17.1 \\
\hline$E(\mathrm{GPa})$ & 205 & 200 & 190 & 117 & N/a & N/a & N/a & N/a & N/a \\
\hline$\sigma_{\mathrm{v}}(\mathrm{MPa})$ & 91 & 94 & 72 & 59 & 49 & 42 & N/a & N/a & N/a \\
\hline$\rho\left(\mathrm{kg} / \mathrm{m}^{3}\right)$ & 8700 & N/a & N/a & N/a & N/a & N/a & N/a & N/a & N/a \\
\hline$v$ & 0.29 & N/a & N/a & N/a & N/a & N/a & $\mathrm{N} / \mathrm{a}$ & N/a & N/a \\
\hline$A$ & N/a & N/a & $\mathrm{N} / \mathrm{a}$ & $1.6 \times 10^{-18}$ & $1.57 \times 10^{-14}$ & $5.53 \times 10^{-11}$ & $8.18 \times 10^{-10}$ & $8.3 \times 10^{-9}$ & $6.26 \times 10^{-8}$ \\
\hline$n$ & 6.6 & 6.6 & 6.6 & 6.6 & 6.6 & 4.6 & 4.6 & 4.6 & 4.6 \\
\hline
\end{tabular}

$T$ temperaure, $K$ thermal conductivity, $C_{p}$ specific heat, $\alpha$ thermal expansion coefficient, $E$ elastic modulus, $\sigma_{\mathrm{v}}$ yield strength, $\rho$ density, $v$ Poisson's ratio, $A$ and $n$ creep law

Table 2 Summary of material properties $\left(\right.$ HAYNES $^{\circledR}$ 214) [41]

\begin{tabular}{|c|c|c|c|c|c|c|c|c|c|}
\hline$T(\mathrm{~K})$ & 298 & 398 & 598 & 798 & 998 & 1098 & 1198 & 1298 & 1398 \\
\hline$K(\mathrm{~W} / \mathrm{m} \mathrm{K})$ & 12 & 12.8 & 15.9 & 21.1 & 26.9 & 29.7 & 31.4 & 32.7 & 34 \\
\hline$C_{p}(\mathrm{~J} / \mathrm{kg} \mathrm{K})$ & 452 & 470 & 515 & 561 & 668 & 705 & 728 & 742 & 749 \\
\hline$\alpha\left(\times 10^{-6} / \mathrm{K}\right)$ & 13.1 & 13.3 & 13.6 & 14.6 & 15.8 & 16.6 & 17.6 & 18.6 & 20.2 \\
\hline$E(\mathrm{GPa})$ & 218 & 210 & 204 & 184 & 170 & 162 & 151 & 137 & N/a \\
\hline$\sigma_{\mathrm{v}}(\mathrm{MPa})$ & 605 & N/a & N/a & 545 & 645 & 610 & 65 & 27 & 12 \\
\hline$\rho\left(\mathrm{kg} / \mathrm{m}^{3}\right)$ & 8700 & N/a & N/a & $\mathrm{N} / \mathrm{a}$ & N/a & $\mathrm{N} / \mathrm{a}$ & $\mathrm{N} / \mathrm{a}$ & $\mathrm{N} / \mathrm{a}$ & $\mathrm{N} / \mathrm{a}$ \\
\hline$v$ & 0.3 & N/a & N/a & $\mathrm{N} / \mathrm{a}$ & N/a & $\mathrm{N} / \mathrm{a}$ & N/a & N/a & $\mathrm{N} / \mathrm{a}$ \\
\hline$A$ & N/a & N/a & $\mathrm{N} / \mathrm{a}$ & N/a & $1.12 \times 10^{-27}$ & $1.48 \times 10^{-18}$ & $1.53 \times 10^{-11}$ & $1.13 \times 10^{-9}$ & $\mathrm{~N} / \mathrm{a}$ \\
\hline$n$ & N/a & N/a & $\mathrm{N} / \mathrm{a}$ & N/a & 9.2 & 5.9 & 5 & 3.2 & $\mathrm{~N} / \mathrm{a}$ \\
\hline
\end{tabular}

$T$ temperaure, $K$ thermal conductivity, $C_{p}$ specific heat, $\alpha$ thermal expansion coefficient, $E$ elastic modulus, $\sigma_{\mathrm{v}}$ yield strength, $\rho$ density, $v$ Poisson's ratio, $A$ and $n$ creep law

Table 3 Summary of alumina properties [42]

\begin{tabular}{llllllllll}
\hline$T(\mathrm{~K})$ & 298 & 398 & 598 & 798 & 998 & 1098 & 1198 & 1298 & 1398 \\
$K(\mathrm{~W} / \mathrm{m} \mathrm{K})$ & 38 & 31 & 19 & 12 & 8 & 7 & 6.8 & 6.5 & 6 \\
$C_{p}(\mathrm{~J} / \mathrm{Kg} \mathrm{K})$ & 771 & N/a & N/a & N/a & N/a & N/a & N/a & N/a & N/a \\
$\alpha\left(\times 10^{-6} / \mathrm{K}\right)$ & 6.9 & 8.1 & 10.1 & 10.7 & 11.1 & 11.3 & 11.4 & 11.6 & N/a \\
$E(\mathrm{GPa})$ & 375 & 375 & N/a & 350 & N/a & 340 & 314 & 305 & N/a \\
$\rho\left(\mathrm{kg} / \mathrm{m}^{3}\right)$ & N/a & N/a & N/a & N/a & N/a & N/a & N/a & N/a & N/a \\
$v$ & 0.28 & 0.28 & 0.28 & 0.3 & 0.32 & 0.32 & 0.35 & 0.37 & 0.37
\end{tabular}

$T$ temperaure, $K$ thermal conductivity, $C_{p}$ specific heat, $\alpha$ thermal expansion coefficient, $E$ elastic modulus, $\rho$ density, $v$ Poisson's ratio, $A$ and $n$ creep law

residual stresses from the elastic-plastic to elastic-plasticcreep calculation is demonstrated. In ABAQUS, this was accomplished in two parts. The first part concerns a transient heat transfer analysis incorporating the nonlinear thermal conductivity and specific heats of nickel, HAYNES $^{\circledR} 214$ and alumina as a function of temperature. Subsequently, the resulting temperature distribution as a function of time was incorporated into the thermal stress analysis.
The transient heat transfer analysis uses second-order elements of DC2D8 type (8-node quadratic heat transfer quadrilateral). The thermal stress analysis is modeled by second-order eight-node biquadratic plane stress elements with nine integration points for each element (CPS8R), which, generally, have superior deformation characteristics. Reduced integration elements were used to decrease the analysis cost and to provide more accurate stresses predictions. Taking advantage of symmetry, only a quarter of the $\mathrm{Al}_{2} \mathrm{O}_{3} / \mathrm{Ni} / \mathrm{Al}_{2} \mathrm{O}_{3}$ sample had been modeled and an half one for the $\mathrm{Al}_{2} \mathrm{O}_{3} / \mathrm{Ni} / \mathrm{HAYNES}^{\circledR} 214$ sample, using boundary conditions (Fig. 3).

\section{Material behavior}

Over about $0.4 T_{\mathrm{m}}$ ( $T_{\mathrm{m}}$ absolute melting temperature), stressed metal and alloys start to creep, that is to say, the rate-dependence of their plasticity behavior becomes significant. The underlying mechanism is an increase in the diffusion of vacancies with temperature. For nickel and its alloys, these vacancies are supposed to diffuse primarily through the lattice at temperatures about $0.4 T_{\mathrm{m}}$ (high creep 
Fig. 3 Schematic representation of the geometry and the mesh configuration used in the FEA simulation. a $\mathrm{Al}_{2} \mathrm{O}_{3} / \mathrm{Ni} / \mathrm{HAYNES}^{\circledR} 214$ and $\mathbf{b} \mathrm{Al}_{2} \mathrm{O}_{3} / \mathrm{Ni} / \mathrm{Al}_{2} \mathrm{O}_{3}$

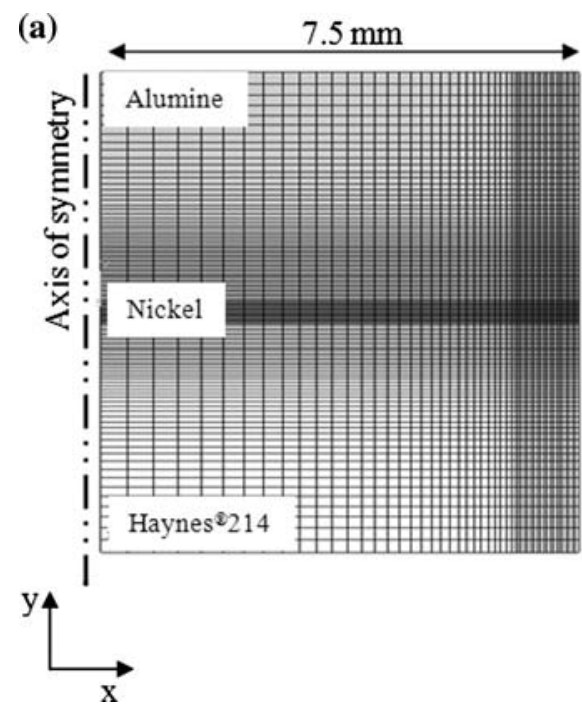

(b)

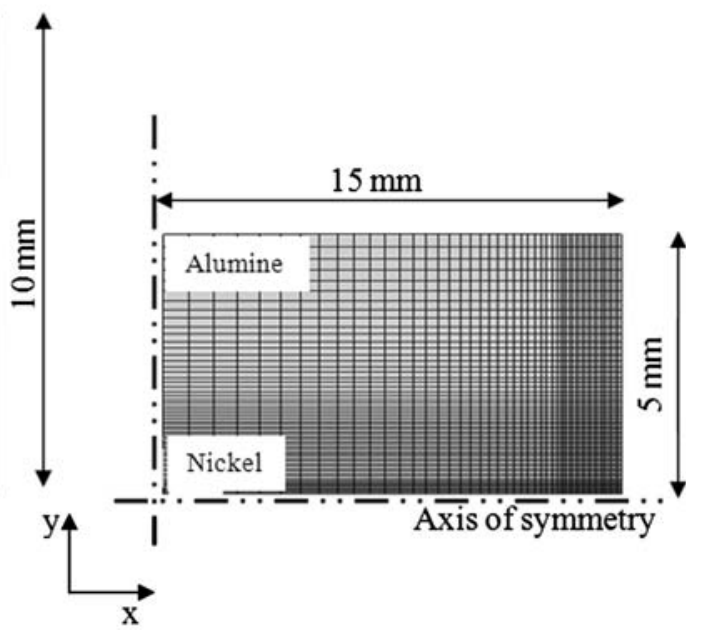

temperature), and along dislocation cores at temperatures between about 0.4 and $0.6 T_{\mathrm{m}}$ (low creep temperature) [21, $34,35]$. A power-law creep model is adopted in both cases. Due to its high melting temperature, the alumina is assumed to behave elastically at all temperatures.

For nickel, in the high temperature creep regime, the creep strain rate $\dot{\varepsilon}$ is expressed as a function of the Mises equivalent stress $\sigma_{\mathrm{e}}$ and the stress exponent is $n$,

$\dot{\varepsilon}=A \sigma_{\mathrm{e}}^{n}$

$A=C \mu^{(1-n)}\left(\frac{b D_{\mathrm{v}}}{K T}\right)$

$D_{\mathrm{v}}=D_{\mathrm{v}_{0}} e^{-\frac{Q_{\mathrm{v}}}{R T}}$

$\mu=\mu_{0}\left(1+\frac{(T-300) T_{\mathrm{m}} d \mu}{T_{\mathrm{m}} \mu_{0} d T}\right)$

where $A, n$ are material constants (power-law creep), $D_{\mathrm{v}}$ is diffusion coefficient $\left(\mathrm{m}^{2} / \mathrm{s}\right), Q_{\mathrm{V}}$ is activation energy (kJ/mole), $b$ is Burgers vector (m), $C$ is constant, and $\mu$ is shear modulus $\left(\mathrm{MN} / \mathrm{m}^{2}\right)$.

Mises equivalent stress is defined as:

$\sigma_{\mathrm{e}}=\sqrt{\frac{3}{2} S: S}$

$S$ is the deviatoric stress tensor defined as $S=\sigma+p I, \sigma$ is the stress, $P$ is the equivalent pressure stress (defined below), and $I$ is a unit matrix. In index notation:

$\sigma_{\mathrm{e}}=\sqrt{\frac{3}{2} S_{i j}: S_{i j}}$

where $S_{i j}=\sigma_{i j}+p \delta_{i j}, p=-\frac{1}{3} \sigma_{i i}$, and $\delta_{i j}$ is the Kronecker delta.

In the low temperature creep regime, the creep strain rate $\dot{\varepsilon}$ is expressed according,
$\dot{\varepsilon}=A \sigma_{\mathrm{e}}^{n+2}$

$A=C \mu^{(1-n)}\left(\frac{b D_{\mathrm{eff}}}{K T}\right)$,

$D_{\text {eff }}=\frac{10 a D_{\mathrm{c}}}{b^{2}}$,

$a_{\mathrm{c}} D_{\mathrm{c}}=\left(a_{\mathrm{c}} D_{\mathrm{c}}\right)_{0} e^{-\frac{Q_{\mathrm{c}}}{R T}}$,

where $\left(a_{\mathrm{c}} D_{\mathrm{c}}\right)_{0}=3.1 \times 10^{-2}$ is the core diffusion coefficient, and $Q_{\mathrm{c}}=170 \mathrm{~kJ} / \mathrm{mol}$ is the core activation energy. The transition temperatures between both regimes vary slightly as a function of the strain rate. In standard experiments, the strain rate during cooling was approximately $10^{-6} / \mathrm{s}$, which corresponds to a transition between high and low creep temperature at $747{ }^{\circ} \mathrm{C}$, and transition between low creep temperature and plasticity at $504{ }^{\circ} \mathrm{C}$. This value provides a much closer correspondence to the peak flow stress in torsion data of Luton and Sellars [34].

Below about $0.4 T_{\mathrm{m}}$, the dominant inelastic deformation mechanism in nickel is the glide of dislocations. Within this regime, a plasticity model with a power-law hardening was assumed. The model is based on the Ramberg-Osgood relationship [35]. The basic one-dimensional model is:

$E \varepsilon=\sigma+\bar{\alpha}\left(\frac{|\sigma|}{\sigma_{0}}\right)^{n-1}$

where $\sigma$ is the stress, $\varepsilon$ is the mechanical strain, $\sigma_{0}$ is the yield stress, $E$ is Young's modulus, $\bar{\alpha}$ is the yield offset in the sense that, when $\sigma=\sigma_{0}, \varepsilon=\frac{\left(1+\bar{\alpha} \sigma_{0}\right.}{E}$, and $n$ is the hardening exponent for the plastic (nonlinear) term.

A linear elastic relation was used to generalize the first term of Eq. 5; the nonlinear term was generalized to multiaxial stress state through the use of the Mises stress potential and associated flow law, giving the multiaxial model [34]: 
$E \varepsilon=(1+v) S-(1-2 v) p I+\frac{3}{2} \bar{\alpha}\left(\frac{\sigma_{\mathrm{e}}}{\sigma_{0}}\right)^{n-1} S$

Tables 1,2, and 3 summarize the thermal and mechanical properties of the materials used in this study.

\section{Results and discussion}

Experimental results

\section{Alumina purity effect}

Primarily, under the experimental conditions applied in this work, the preliminary bonding experiments using $\mathrm{Ni}$ interlayer were successful only when alumina contains low sintering adding. It is suggested that above $1050{ }^{\circ} \mathrm{C}$, a capillary mechanism acts mainly on bonding, favoring the migration of the secondary phase material from the alumina (S) triple grain boundaries points, allowing high concentrations of impurity at the interface $[3,36]$. SEM fractography has revealed vitreous layers at $\mathrm{Al}_{2} \mathrm{O}_{3} / \mathrm{Ni}$ interface (Fig. 4). This later can affect seriously the strength of the joints. The rupture is adhesive at the alumina/Nickel interface (Fig. 5). The test carried out with HP alumina (AL23) yield to better results; this pure alumina will be used for the continuation of this study.

\section{Interface microstructure evaluation}

The cross section of the $\mathrm{Al}_{2} \mathrm{O}_{3} / \mathrm{Ni}$ interface formed by diffusion bonding at $1150{ }^{\circ} \mathrm{C}$ for $1 \mathrm{~h}$, using a $0.2-\mathrm{mm}$ interlayer, is shown in Fig. 6a. After the shear test, a spinel

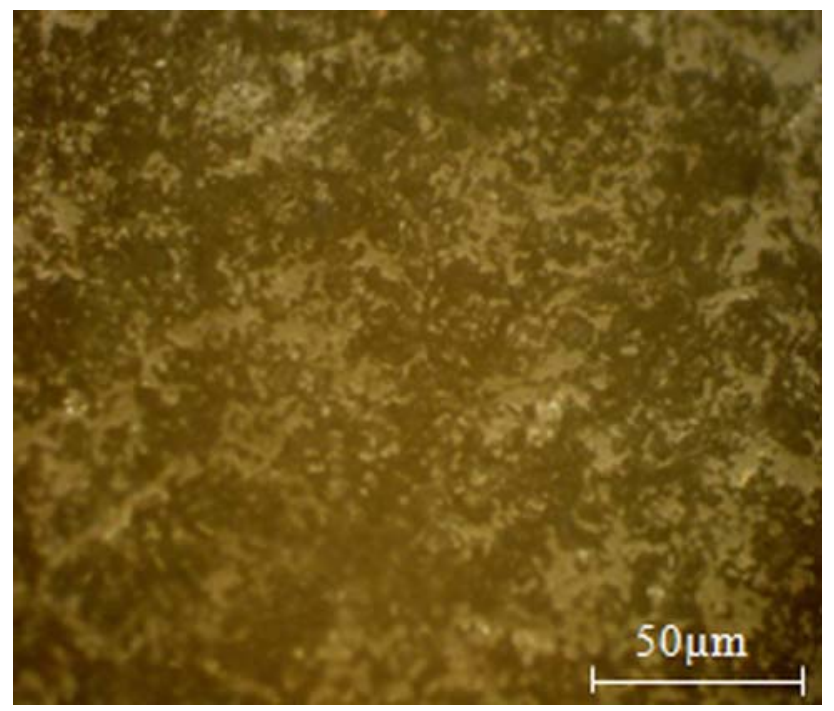

Fig. 4 Optical micrograph of the A99 alumina after bonding with HAYNES $^{\circledR} 214\left(T=1150{ }^{\circ} \mathrm{C}, P=16 \mathrm{MPa}, t=1 \mathrm{~h}\right)$
$\left(\mathrm{NiAl}_{2} \mathrm{O}_{3}\right)$ phase was identified by EDS microanalysis and confirmed by GIXRD (Fig. 6b, c). The observation of spinel $\left(\mathrm{NiAl}_{2} \mathrm{O}_{3}\right)$ at the interface suggests the oxygen activity in the system is relatively high. When the oxygen partial pressure is above the threshold, or/and the oxygen dissolved into nickel foil is above a critical level, nickel aluminate spinel $\left(\mathrm{NiAl}_{2} \mathrm{O}_{3}\right)$ forms at the interface [15]. Figure $6 \mathrm{~b}$ shows that the spinel layer is discontinuous. Residuals interface pores are the major strength limiting flaws in ceramic/metal joint $[37,38]$. We mentioned that no residual porosity was observed at the scale used for our observation. In fact, both high diffusion time $(1 \mathrm{~h})$ and applied pressure (16 MPa) eliminated this porosity (Fig. 6a). Consequently, the possibility of the influence of the residual pores and/or spinel grains in stress concentration was neglected. In the same way, the interdiffusion $(\mathrm{Cr}, \mathrm{Fe} \ldots)$ at the interface Ni-alloy is weak $(<10 \mu \mathrm{m})$ and affects little the properties (hardness, thickness) of the nickel interlayer. We will neglect also his effect for simulation.

Bond strength of $\mathrm{Al}_{2} \mathrm{O}_{3} / \mathrm{Al}_{2} \mathrm{O}_{3}$ joints and $\mathrm{Al}_{2} \mathrm{O}_{3} / \mathrm{HAYNES} \mathrm{S}^{\circledR}$ 214 joints

The influence of the bonding temperature on the room temperature strengths of the joints is shown in Fig. 5. The results demonstrate that the bond strength of the $\mathrm{Al}_{2} \mathrm{O}_{3}$ / $\mathrm{Al}_{2} \mathrm{O}_{3}$ joint is much higher than that of the $\mathrm{Al}_{2} \mathrm{O}_{3} /$ HAYNES $^{\circledR} 214$ joint using the same solid-state bonding conditions. So, it can be concluded that this difference is mainly caused by the thermal property mismatch between these two base materials. The coefficients of thermal expansion (CTEs) of HAYNES ${ }^{\circledR} 214$ and nickel are almost twice that of $\mathrm{Al}_{2} \mathrm{O}_{3}$ at room temperature (Tables 1 and 3). The CTEs of all materials increase with increasing temperature; however, the increments are different and thus the differences become even larger with increasing temperature. During the current investigation, the mating surfaces of ceramic and metal were brought into contact, with each other, at high temperature in order to enable a bond to be achieved between them. Once a joint had formed, a slow cooling was executed. Due to the large difference in thermal shrinkage between the metal and the ceramic, thermal stresses are induced at the brazed region during cooling from bonding temperature to room temperature. These thermal stresses result in plastic deformation of the metal, cracking within the ceramic, or interfacial decohesion, and cause strength degradation or even premature failure of the joint.

Comparing different fabrication conditions (Fig. 5a-c), we can see that the shear strength in the case of $\mathrm{Al}_{2} \mathrm{O}_{3}$ / HAYNES $^{\circledR} 214$ joint at $1200{ }^{\circ} \mathrm{C}$ has a high value. Because there was a large plastic deformation of the alloy, these 

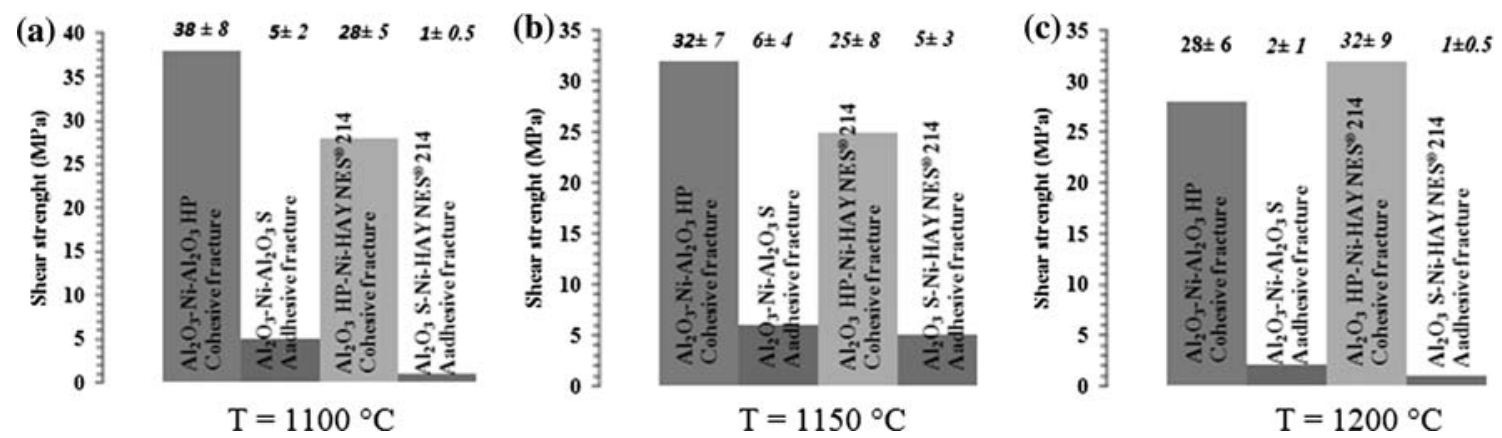

Fig. 5 Average shear strength of joints, bonded with Ni interlayer, obtained at several bonding temperatures a $1100{ }^{\circ} \mathrm{C}$, b $1150{ }^{\circ} \mathrm{C}$, and c $1200{ }^{\circ} \mathrm{C}$
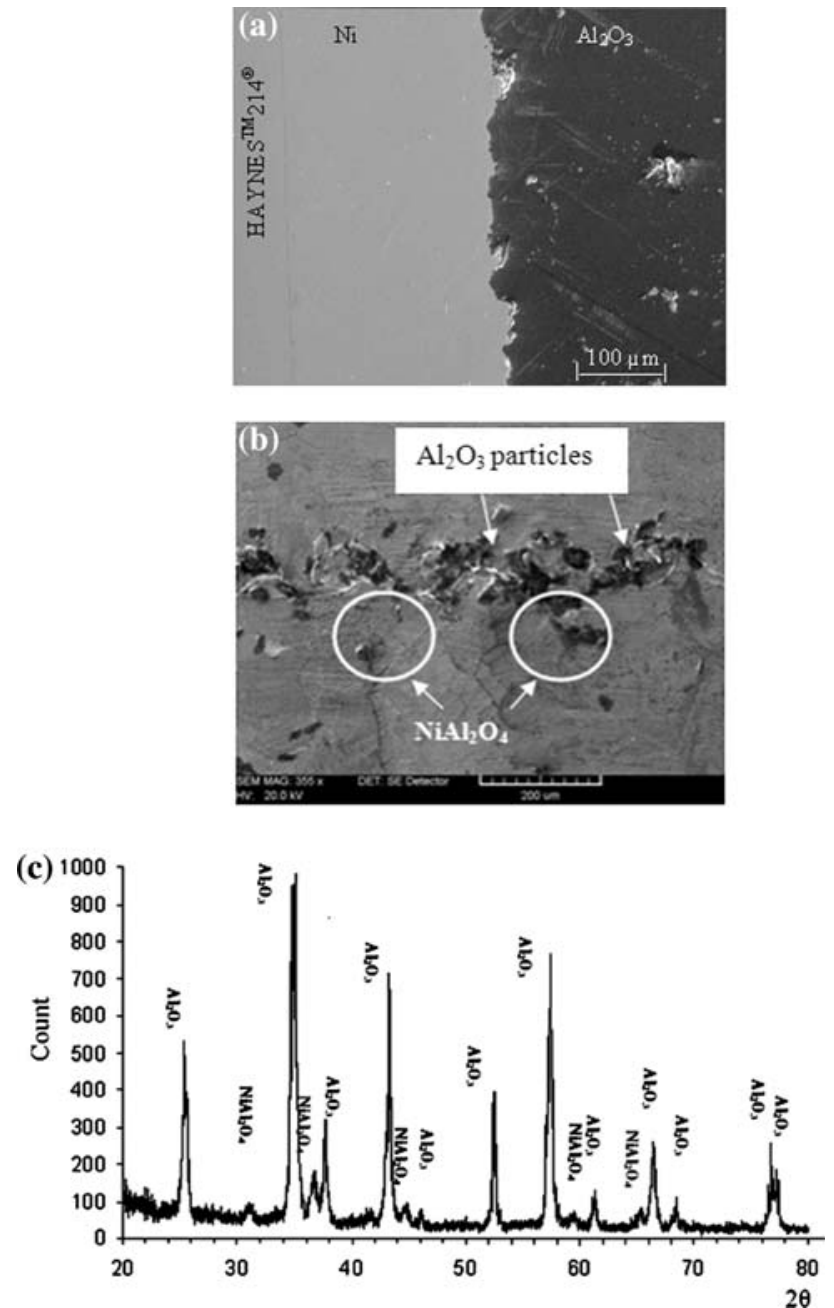

Fig. 6 a Cross section of $\mathrm{Al}_{2} \mathrm{O}_{3} / \mathrm{Ni}$ interface formed by diffusion bonding, b SEM micrograph of sample diffusion bonded at $1150{ }^{\circ} \mathrm{C}$ for $60 \mathrm{~min}$, showing the top of $\mathrm{Ni}$ after fracture of $\mathrm{Al}_{2} \mathrm{O}_{3} / \mathrm{Ni}$ interface, and $\mathbf{c}$ GIXRD diffraction patterns of high purity alumina bonding area $\left(\lambda_{K \alpha} \mathrm{Cu}\right)$

conditions have been abandoned. Other observations indicate that, when using Alumina A99 (S) the rupture is adhesive whereas when using Alumina AL23 (HP) the rupture is cohesive in the alumina material.

\section{Effect of the thicknesses of alloy and metal interlayer}

To highlight the effect of thickness of metal (Ea) on strength shear test of joint, $\mathrm{Al}_{2} \mathrm{O}_{3} / \mathrm{Ni} / \mathrm{HAYNES}^{\circledR} 214$ joints with different alloy thicknesses and the same $\mathrm{Ni}$ interlayer $(0.2 \mathrm{~mm}$ thick) were fabricated. The results of those tests are shown in Table 4: when the thickness of alumina material (Ec) is higher than the thickness of HAYNES ${ }^{\circledR}$ 214 alloy (Ea) $\left(R^{\prime}=\mathrm{Ec} / \mathrm{Ea}>1\right)$, no bonding were obtained. Best joints are obtained for $R^{\prime} \leq 1$.

The effect of $\mathrm{Ni}$ interlayer thickness was also studied in $\mathrm{Al}_{2} \mathrm{O}_{3} / \mathrm{Ni} / \mathrm{HAYNES}^{\circledR} 214$ joints (Table 5). The major studies of metal-ceramic bond were devoted to symmetrical joints (i.e., ceramic/metal/ceramic) [4, 7, 13, 25]. In this case, the trend to lower bond strength with thicker metal interlayer is due to the increasing influence of the free edge stress concentrations at a given applied load [38]. Consequently, a thin metal interlayer is favorable to reduce residual stresses. However, the dissymmetrical joints (i.e., ceramic/metal/alloy) present the opposite behavior. Consequently, a thick metal interlayer reduces residual stresses. In the same way, the simulations described in the literature generally relate to symmetrical joints and elastoplastic models. This work shows well that the results in symmetrical systems cannot be applied to ceramics/alloys joints. To confirm this result, FE analysis will be able to predict

Table 4 Effect of ceramics thickness on strength of $\mathrm{Al}_{2} \mathrm{O}_{3} / \mathrm{Ni} /$ HAYNES $^{\mathrm{TM}} 214^{\circledR}$ joint obtained using conditions described in Fig. 1

\begin{tabular}{llll}
\hline Joint & $\begin{array}{l}\text { Experimental } \\
\text { conditions }\end{array}$ & $\begin{array}{l}\text { Shear } \\
\text { strength } \\
(\mathrm{MPa})\end{array}$ & $\begin{array}{l}\text { Type of } \\
\text { failure }\end{array}$ \\
\hline $\mathrm{Al}_{2} \mathrm{O}_{3} / \mathrm{Ni} / \mathrm{HAYNS}^{\mathrm{TM}} 214^{\circledR}$ & $R^{\prime}=1.66$ & 0 & - \\
$\mathrm{Al}_{2} \mathrm{O}_{3} / \mathrm{Ni} / \mathrm{HAYNS}^{\mathrm{TM}} 214^{\circledR}$ & $R^{\prime}=1.25$ & 0 & - \\
$\mathrm{Al}_{2} \mathrm{O}_{3} / \mathrm{Ni} / \mathrm{HAYNS}^{\mathrm{TM}} 214^{\circledR}$ & $R^{\prime}=1$ & $35 \pm 7$ & Cohesive \\
$\mathrm{Al}_{2} \mathrm{O}_{3} / \mathrm{Ni} / \mathrm{HAYNS}^{\mathrm{TM}} 214^{\circledR}$ & $R^{\prime}=0.5$ & $25 \pm 5$ & Cohesive \\
\hline
\end{tabular}

$R^{\prime}=\mathrm{Ec} / \mathrm{Ea}$, ratio between the thickness of the ceramics and the thickness of the alloy $(\mathrm{Ea}=5 \mathrm{~mm})$ 
Table 5 Effect of Ni interlayer thickness on strength of $\mathrm{Al}_{2} \mathrm{O}_{3} / \mathrm{Ni}$ / HAYNES $^{\mathrm{TM}} 214^{\circledR}$ joints $\left(R^{\prime}=1\right.$, other parameters are described in Fig. 1)

\begin{tabular}{llll}
\hline Joint & $\begin{array}{l}\text { Ni interlayer } \\
\text { thickness } \\
(\mathrm{mm})\end{array}$ & $\begin{array}{l}\text { Shear } \\
\text { strength } \\
(\mathrm{MPa})\end{array}$ & $\begin{array}{l}\text { Type of } \\
\text { failure }\end{array}$ \\
\hline $\mathrm{Al}_{2} \mathrm{O}_{3} / \mathrm{Ni} / \mathrm{HAYNS}^{\mathrm{TM}} 214^{\circledR}$ & 0.1 & $11 \pm 3$ & Cohesive \\
$\mathrm{Al}_{2} \mathrm{O}_{3} / \mathrm{Ni} / \mathrm{HAYNS}^{\mathrm{TM}} 214^{\circledR}$ & 0.2 & $25 \pm 2$ & Cohesive \\
$\mathrm{Al}_{2} \mathrm{O}_{3} / \mathrm{Ni} / \mathrm{HAYNS}^{\mathrm{TM}} 214^{\circledR}$ & 0.3 & $28 \pm 2$ & Cohesive \\
$\mathrm{Al}_{2} \mathrm{O}_{3} / \mathrm{Ni} / \mathrm{HAYNS}^{\mathrm{TM}} 214^{\circledR}$ & 0.5 & $35 \pm 4$ & Cohesive \\
\hline
\end{tabular}

the effect of interlayer thickness and geometry of joint and their optimum.

FEA results

\section{Effect of the FEA model choice}

The effect of the metal properties on the evolution of the thermal residual stress is discussed for both $\mathrm{Al}_{2} \mathrm{O}_{3}-\mathrm{Al}_{2} \mathrm{O}_{3}$ and $\mathrm{Al}_{2} \mathrm{O}_{3}-\mathrm{HAYNES}^{\circledR} 214$ joints. The comparison is made between the coupled creep and plasticity model and the equivalent model without creep. The effect of addition of the creep relaxation to the plastic calculation is examined: the decrease in the residual stress from elasticplastic (564 MPa) to elastic-plastic-creep (234 MPa) calculation is illustrated in Fig. 7. For both joints, the maximum of $\sigma_{y}, \sigma_{x y}$, and $\sigma_{x}$ stresses clearly decreases between the elasto-plastic and elastic-plastic-creep models. This decrease is very significant in the case of $\mathrm{Al}_{2} \mathrm{O}_{3}-$ HAYNES $^{\circledR} 214$ joint.

The residual stresses in Alumina and HAYNES ${ }^{\circledR} 214$ are distributed almost symmetrically corresponding to an origin. The residual stress of center line is in compression in ceramics and in tension in alloy. Those stresses are distributed continuously and smoothly in whole specimen.

\section{Residual stress distribution in EPC model}

Figure 8 shows the contour plots in the elastic-plasticcreep model of the thermal residual stress distribution for $\mathrm{Al}_{2} \mathrm{O}_{3}-\mathrm{Al}_{2} \mathrm{O}_{3}$ or $\mathrm{Al}_{2} \mathrm{O}_{3}-\mathrm{HAYNES}^{\circledR} 214$ joints using a
Fig. 7 Comparison between elastic-plastic-creep (EPC) and elastic-plastic (EP) model for $\mathrm{Al}_{2} \mathrm{O}_{3} / \mathrm{Ni} / \mathrm{Al}_{2} \mathrm{O}_{3}$ or $\mathrm{Al}_{2} \mathrm{O}_{3} / \mathrm{Ni} /$ HAYNES $^{\circledR} 214^{\mathrm{TM}}$ joints with $0.2-\mathrm{mm}$ thick $\mathrm{Ni}$ interlayer. This profile is drawn according to the stresses level over an imaginary line passing through field of maximum value of stress

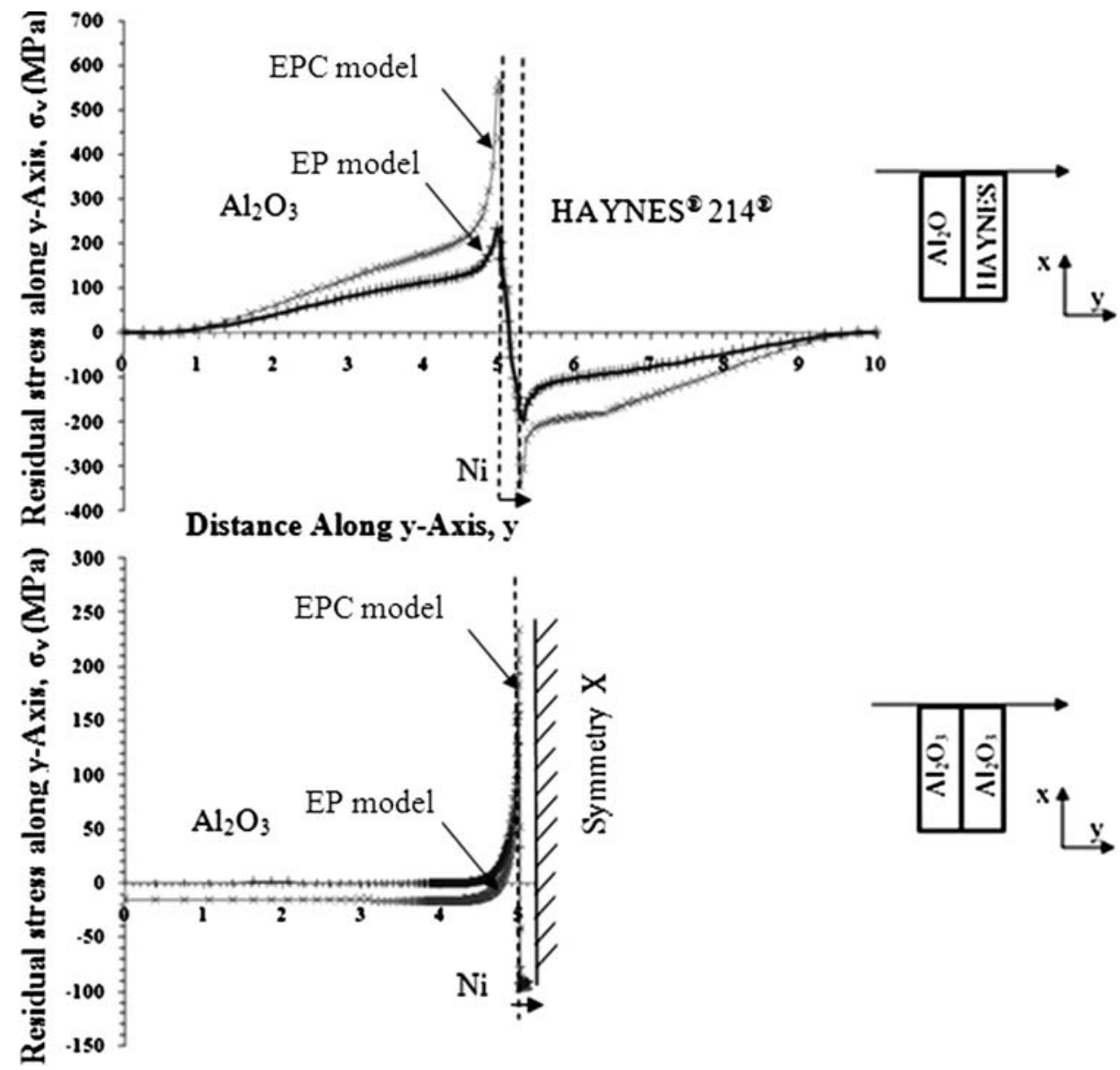


Fig. 8 Contours plots of the thermal residual stress distribution for the $\mathrm{Al}_{2} \mathrm{O}_{3} / \mathrm{Ni} /$ $\mathrm{Al}_{2} \mathrm{O}_{3}$ and $\mathrm{Al}_{2} \mathrm{O}_{3} / \mathrm{Ni} / \mathrm{HAYNES}^{\circledR}$ 214 joint with $0.2 \mathrm{~mm}$ thick $\mathrm{Ni}$ interlayer in EPC model a $\sigma_{x}$ b $\sigma_{y}$, and $\mathbf{c} \sigma_{x y}$ (a)

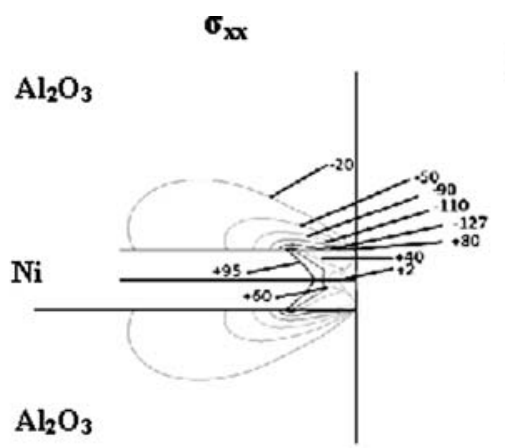

(b)

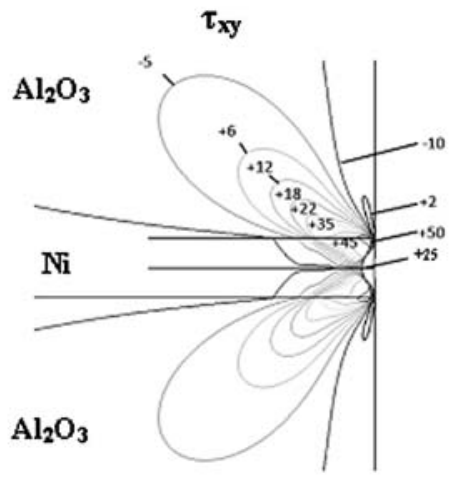

$\sigma_{y y}$

(c)

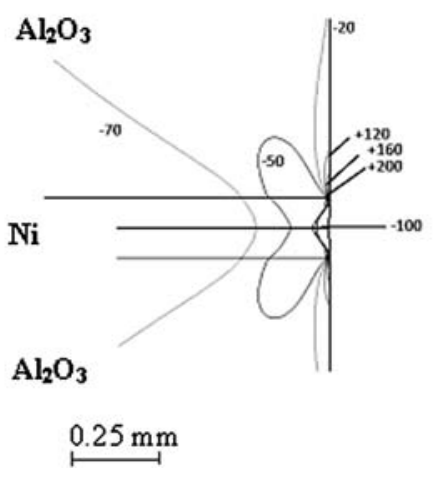

(a)

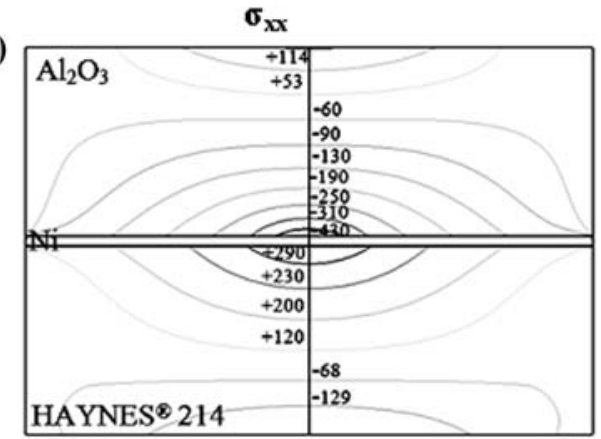

$\tau_{x y}$

(b)

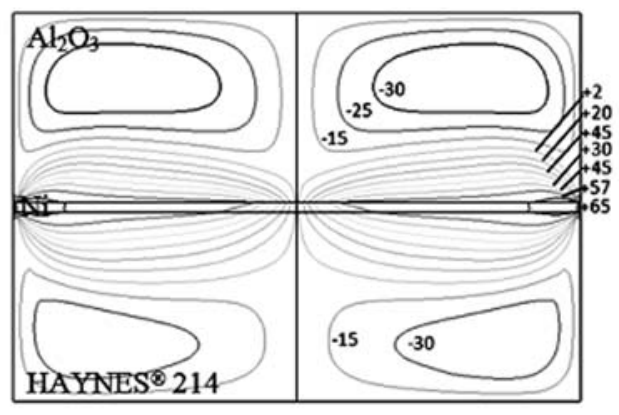

(c)

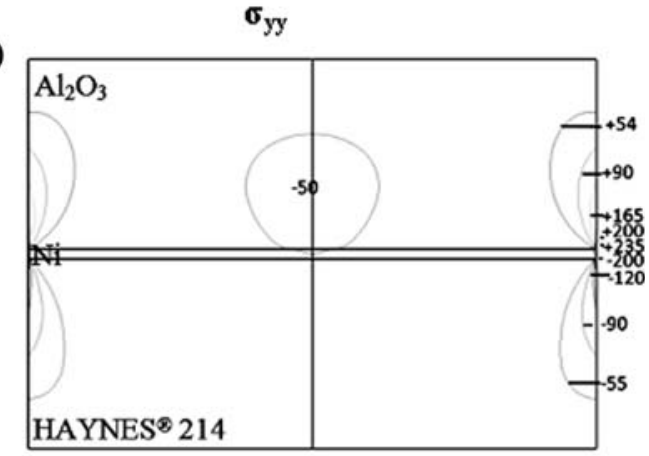

$2.5 \mathrm{~mm}$ $0.2-\mathrm{mm} \mathrm{Ni}$ interlayer. For the present discussion, it is convenient to describe the residual stress in term of three main components: (i) the main stress $\sigma_{y}$, perpendicular to the interface; (ii) $\sigma_{x}$ represents the stress in the directions parallel to the interface between the ceramic and the metal, and (iii) $\tau_{x y}$ represents the shear stress acting on a plane parallel to the bonding interface. To analyze in detail, the stress distribution in the $\mathrm{Al}_{2} \mathrm{O}_{3}-\mathrm{HAYNES}^{\circledR} 214$ joint, the stresses distribution was plotted in Fig. 8c: we can observe that $234 \mathrm{MPa}$ tensile stress is reached at the free surface of the ceramic material, decreasing rapidly when approaching the center. The same behavior has been noted in the case of $\mathrm{Al}_{2} \mathrm{O}_{3}-\mathrm{Al}_{2} \mathrm{O}_{3}$ joint, but with a lower stress, at about $200 \mathrm{MPa}$.
Additionally, $\sigma_{y}$ tensile stresses in the ceramic side are highest in the free end, near the interface; the shear stresses are also maximum in this same zone. The presence of shear stresses at the ceramic side, near the metal-ceramic interface, in combination with the tensile stresses that are present, can induce fracturing in ceramics, because ceramics have poor fracture toughness, particularly near the metal-ceramic interface $\left(4 \mathrm{MPa} \mathrm{m}^{-1 / 2}\right)$ [4]. The cracks under the effect of high residual stress will downgrade the ceramic properties and may even lead to fracture [10]. Through fractographic analysis of the shear specimens, it is confirmed that the crack is initiated close to the free edge of the sample, on defects located in the $\mathrm{Ni} / \mathrm{Al}_{2} \mathrm{O}_{3}$ interface and then changes its direction, and propagates into the 
Fig. 9 a Crack propagation in $\mathrm{Al}_{2} \mathrm{O}_{3}-\mathrm{HAYNES}^{\circledR} 214$ joint and $\mathbf{b}$ prediction of the direction of crack propagation by FEA
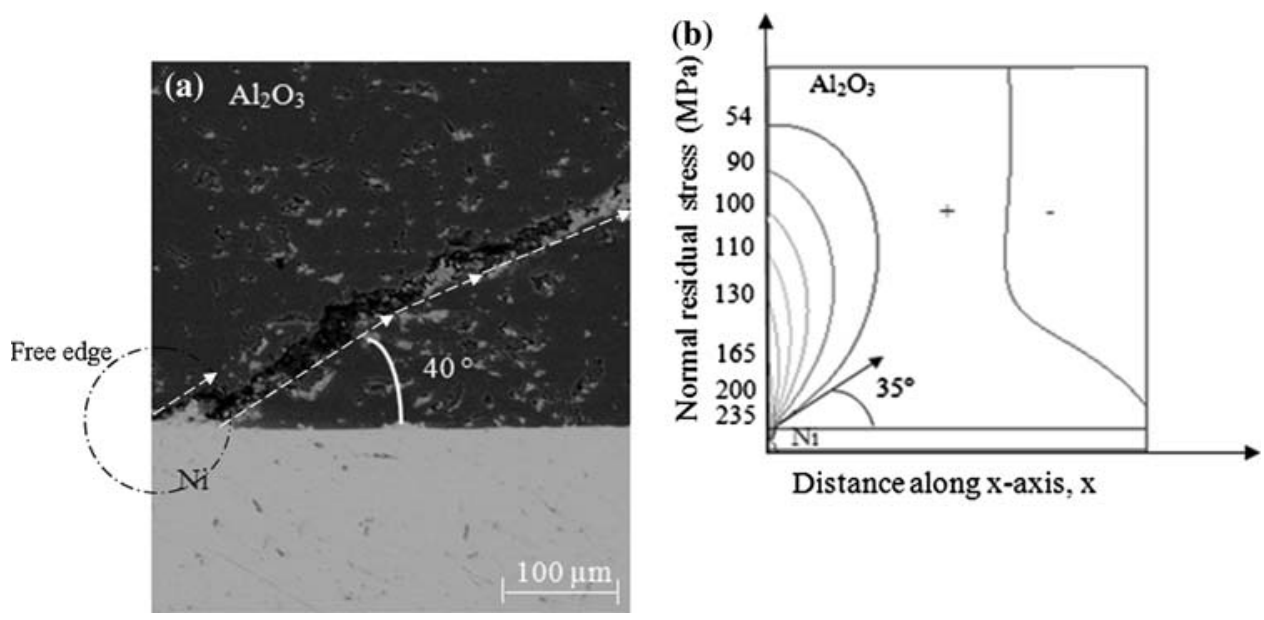

ceramics bulk, near the interface, with an angle equal to about $40^{\circ}$ (Fig. 9a). This type of fracture suggests that the ceramic parts near the interface have high tensile residual stresses and are prone to cracking, as predicted by FEA. In accordance with our observations, the experimental angle of $40^{\circ}$ corresponds approximately to the direction of the maximal tension stress, normal to the interface, determined by FEA (Fig. 9b). The stresses components most significant in fracture of ceramic-metal joints are the tension and shear stresses at the free edge. Tension stress concentrations near the specimen edge can cause fracture within the ceramics, in the case of strongly bonded systems, or delamination at the interface for weakly bonded systems. In some cases, large plastic strains in the metal can also promote fracture due to growth and coalescence of voids [10].

\section{Effect of the interlayer thickness}

FEA was also used to monitor the effects of $\mathrm{Ni}$ thickness on the residual stress levels. Several competing processes were used to optimize value for interlayer thickness and determine the final stress distribution. For the $\mathrm{Al}_{2} \mathrm{O}_{3}-\mathrm{Al}_{2} \mathrm{O}_{3}$ joint, when the interlayer thickness is decreased, the levels of residual stress in the joint are reduced, contrary to the residual stresses in the $\mathrm{Al}_{2} \mathrm{O}_{3}-\mathrm{HAYNES}^{\circledR} 214$ joint; but, an optimal thickness exists (Fig. 10). This corresponds to the experimental observations previously presented (Table 5). In the same way, the geometry of the joint also plays a significant role on the intensity of the residual stresses, especially by the ratio $R=h / l$ where $l$ is the length of the contact and " $h$ " the thickness of the seal.

If $R$ increases, lower residual stresses are observed for $\mathrm{Al}_{2} \mathrm{O}_{3} / \mathrm{Ni} / \mathrm{HAYNES}^{\circledR} 214$ joints but higher stresses for $\mathrm{Al}_{2} \mathrm{O}_{3} / \mathrm{Ni} / \mathrm{Al}_{2} \mathrm{O}_{3}$ joints (Fig. 11). The optimum was obtained for $R=0.033\left(\mathrm{Al}_{2} \mathrm{O}_{3} / \mathrm{Ni} / \mathrm{HAYNES}^{\circledR} 214\right)$ and $R=0.0083$ for $\left(\mathrm{Al}_{2} \mathrm{O}_{3} / \mathrm{Ni} / \mathrm{Al}_{2} \mathrm{O}_{3}\right)$.

\section{Effect of the ceramics thickness}

Figure 12 shows clearly that the residual stresses depend on the thickness of the ceramics or more certainly on the ratio $R^{\prime}$ between the thickness of the ceramics and the thickness of the alloy "Ec/Ea": $\mathrm{Ec} / \mathrm{Ea}<1$ is recommended. Previously, a similar experimental result was presented (Table 4). The optimum was obtained for $R^{\prime}=0.06$ in the case of $\mathrm{Al}_{2} \mathrm{O}_{3} / \mathrm{Ni} / \mathrm{HAYNES}^{\circledR} 214$ (Fig. 12). However, in experiments, it seems that the resistance of the joint is worse if the thickness of the ceramics is too reduced. Indeed, we noted, during the preparation of specimens, that a ceramics of low thickness (Ec $=0.3 \mathrm{~mm}, \mathrm{Ea}=5 \mathrm{~mm}$ ) is cracking during fabrication which prevented any bonding.

This shows well the limitations of the FEA which does not take into account all the parameters intervening during the fabrication of metal-ceramic joints. In particular, the diffusion of nickel in alumina is not taken into account, whereas diffusion of metal, especially along the grain boundaries, induces the fall of the ceramics toughness in the vicinity of the interface, therefore alumina becomes more brittle [4, 39]. When Ec $\leq 0.3 \mathrm{~mm}$, the scale effect becomes significant and favors the fracture under the effect of residual stresses, applied load, and lower ceramics toughness near the interface.

\section{Conclusions}

Residual thermal stresses, developed during the fabrication of both $\mathrm{Al}_{2} \mathrm{O}_{3}-\mathrm{Al}_{2} \mathrm{O}_{3}$ and $\mathrm{Al}_{2} \mathrm{O}_{3}-\mathrm{Ni}$ alloy (HAYNES $^{\circledR}$ 
Fig. 10 Predicted variation of tensile stress normal to interfaces with interlayer thickness of nickel $(0.125,0.25$, and $0.5 \mathrm{~mm}$ ) in both $\mathrm{Al}_{2} \mathrm{O}_{3} / \mathrm{Ni} /$ $\mathrm{Al}_{2} \mathrm{O}_{3}$ or $\mathrm{Al}_{2} \mathrm{O}_{3} / \mathrm{Ni} / \mathrm{HAYNES}^{\circledR}$ 214 joints in EPC model

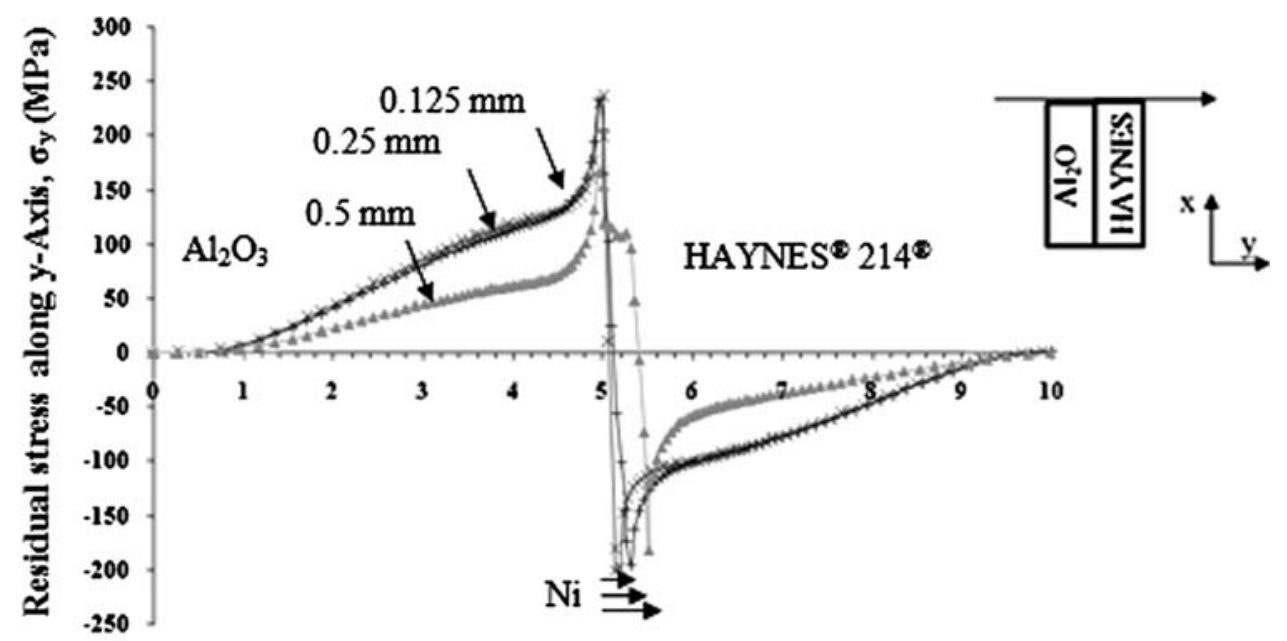

Distance Along y-Axis, y

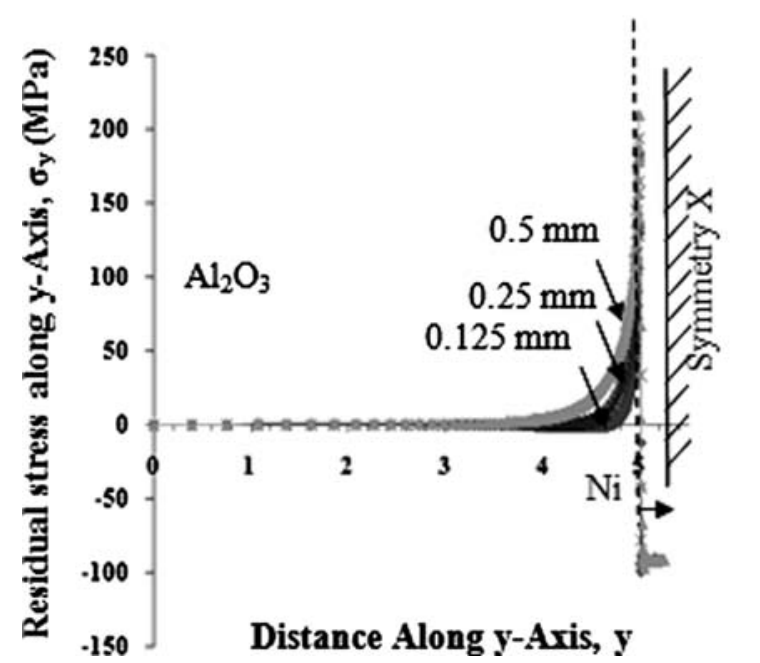

214) joints have been studied by the elastic-plastic and the elastic-plastic-creep finite element numerical analysis (FEA) and compared with fracture strength measurements. Based on the results obtained in this work, the following conclusions can be drawn:

1. The choice of the purity of alumina material is important for the mechanical behavior of joints. Taking into account the high temperatures of the assembly, an alumina material rich in sintering addings can induce a flow of the intergranular phases on the surface of alumina, penalizing for the mechanical resistance.

2. In the case of $\mathrm{Al}_{2} \mathrm{O}_{3}-\mathrm{HAYNES}^{\circledR} 214$ joints, it is necessary to use the creep model, whereas, in the case of $\mathrm{Al}_{2} \mathrm{O}_{3}-\mathrm{Al}_{2} \mathrm{O}_{3}$ joints, the difference between the elasticplastic and the elastic-plastic-creep results is small.

3. The residual stresses concentration of the $\mathrm{Al}_{2} \mathrm{O}_{3}-$ HAYNES $^{\circledR} 214$ joint is much higher than for the
$\mathrm{Al}_{2} \mathrm{O}_{3}-\mathrm{Al}_{2} \mathrm{O}_{3}$ one. Therefore, the formation of cracks on the free edge is easier for the first system, inducing also low mechanical characteristics.

4. The importance of the geometry of the joint, characterized by the ratio $R=h / l$, where $\mathrm{i}$ is the length of the contact area and " $h$ " the thickness of the $\mathrm{Ni}$ foil, is confirmed. For $\mathrm{Al}_{2} \mathrm{O}_{3}-$ HAYNES $^{\circledR} 214$ joints, a low ratio can induce higher residual stress concentrations leading to the brittleness. The optimum for this case is $R=0.033$. By contrast, in the case of $\mathrm{Al}_{2} \mathrm{O}_{3}-\mathrm{Al}_{2} \mathrm{O}_{3}$ joints, a low ratio minimizes residual stresses. The optimum for this case is $R=0.0083$.

5. The role of the relative dimensions of alloy and ceramics $\left(R^{\prime}\right.$ ratio $=$ thickness of ceramics Ec/thickness Ea of metal). A high thickness of ceramics is harmful. The optimum is obtained for $R^{\prime}=0.06$. However, in experiments, a too low thickness of ceramics is harmful. 

of tensile stress normal to interfaces with ratio $R$ in both $\mathrm{Al}_{2} \mathrm{O}_{3} / \mathrm{Ni} / \mathrm{Al}_{2} \mathrm{O}_{3}$ or $\mathrm{Al}_{2} \mathrm{O}_{3} / \mathrm{Ni} / \mathrm{HAYNES}^{\circledR}$ 214 joints in EPC model
Fig. 11 Predicted variation

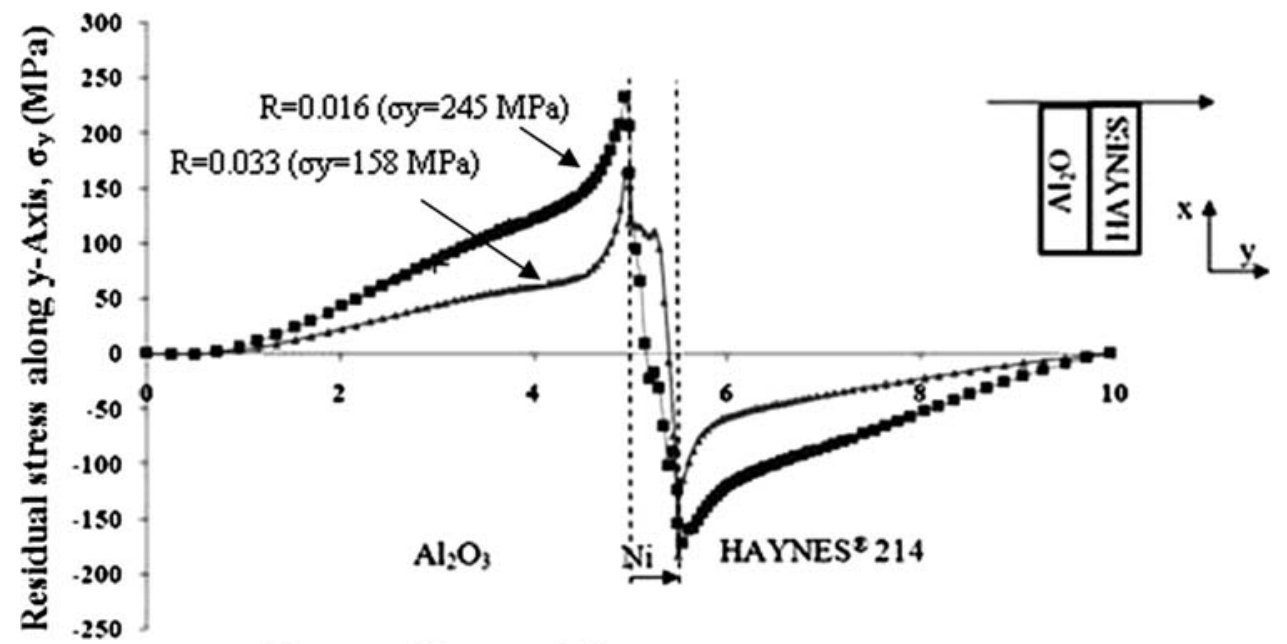

Distance Along y-Axis, y
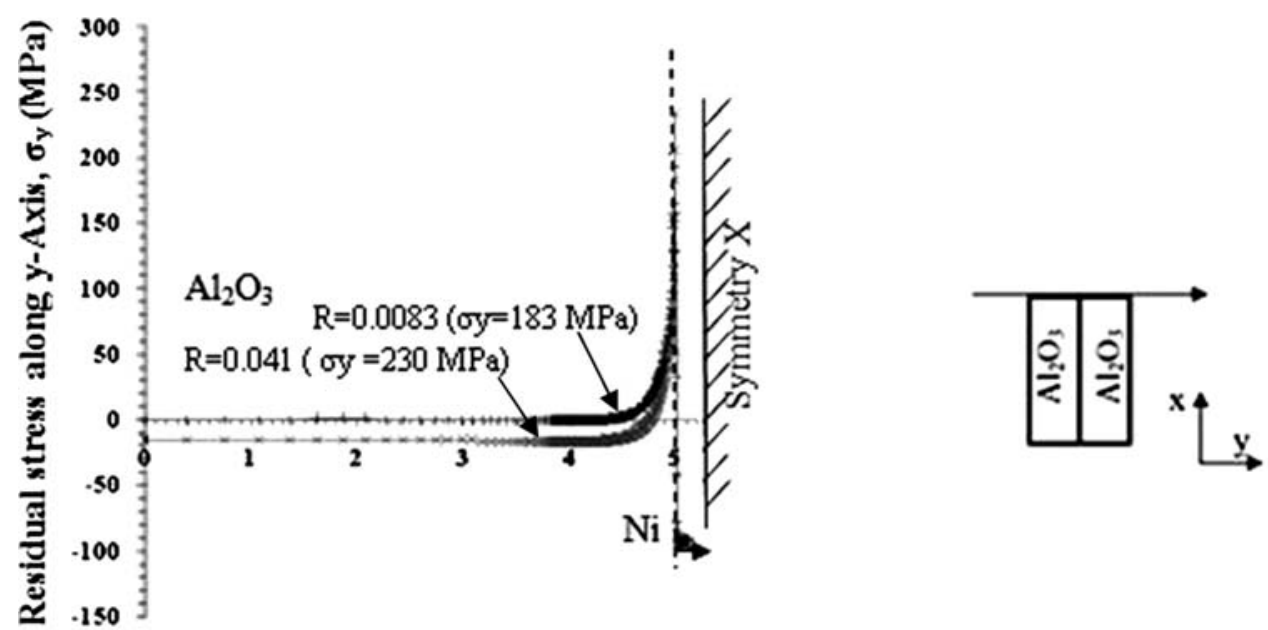

Distance Along y-Axis, y

Fig. 12 Predicted variation of tensile stress normal to interfaces with varying

thickness of alumina (Ec) for $\mathrm{Al}_{2} \mathrm{O}_{3} / \mathrm{Ni} / \mathrm{HAYNES}^{\circledR} 214$ joints in $\mathrm{EPC}$ model $(\mathrm{Ea}=5 \mathrm{~mm})$

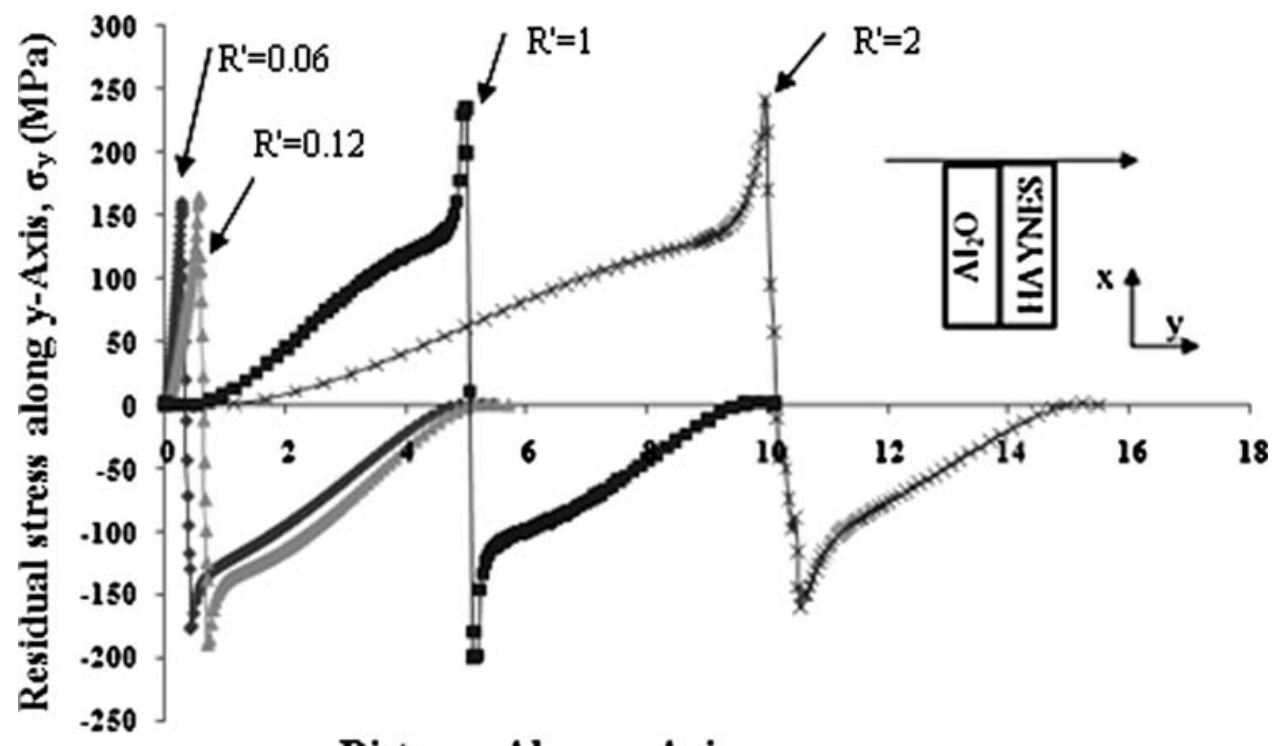

Distance Along y-Axis, y 


\section{References}

1. Foley AG, Andrews DJ (1994) Tech Rev 13:64

2. Lemus-Ruiz J, Ceja-Cardenas L, Verduzco JA, Osvaldo F (2008) J Mater Sci 43(18):6296. doi:10.1007/s10853-008-2894-5

3. Lourdin P, Juvé D, Tréheux D (1996) J Eur Ceram Soc 16(7):745

4. Serier B, Tréheux D (1993) Acta Metall Mater 41(2):369

5. Zhang Y, Feng D, He ZY, Chen XC (2006) J Iron Steel Res Int 13(2): 1

6. Das S, Tiwar AN, Kulkarni AR (2004) J Mater Sci 39:3345. doi: 10.1023/B:JMSC.0000026935.18466.4b

7. Locatelli MR, Dalgleish BJ, Nakashima K, Tomsia AP, Glaeser AM (1997) Ceram Inter 23:313

8. Gauffier A, Saiz E, Tomsia AP, Hou PY (2007) J Mater Sci 42(23):9524. doi:10.1007/s10853-007-2093-9

9. Kar A, Mandal S, Ghosh RN, Ghosh TK, Ray AK (2007) J Mater Sci 42(14):5556. doi:10.1007/s10853-006-1092-6

10. Zhang JX, Chandel YZ, Seow HP (2002) J Mater Proc Tech 122:220

11. Schwartz MM (1990) Ceramic joining. ASM International, Metals Park, $\mathrm{OH}$

12. Zhang Y, Feng D, He ZY, Chen XC (2006) J Iron Steel Res 13(2): 1

13. Tréheux D, Lourdin P, Mbongo B, Juve D (1994) Scripta Metall Mater 31(8):105511

14. Wan C, Dupeux M (1993) J Mater Sci 28:5079. doi:10.1007/ BF00361183

15. Zhang W, Smith JR, Evans AG (2002) Acta Mater 50:3803

16. Florjancic M, Mader W, Rühle M, Turwitt M (1985) J Phys 46C4:129

17. Morozumi S, Kikuchi S, Nishio T (1981) J Mater Sci 16:2137. doi:10.1007/BF0054374

18. Lu YC, Sass SL, Bai Q, Kohlstedt DL, Gerberich WW (1995) Acta Metall Mater 43:31

19. Heikinheimo LSK, de With G (1996) International Institute of Welding, Report IIW Doc IX, $1827 \mathrm{p}$

20. Trumble KP, Ruhle M (1991) Acta Metall Mater 39:1915

21. Tang S, Zehnder AT (2002) Eng Frac Mech 69:701

22. Ohuchi FS, French RH, Kasowski RV (1987) J Appl Phys 62(6):31
23. Beraud C, Esnouf C (1990) Microsc Microanal Microstruct 1:69

24. Hattali ML, Valette S, Ropital F, Stremsdoerfer G, Mesrati N, Tréheux D (2009) J Eur Ceram Soc 29:813

25. Calow CA, Bayer PB, Porter IT (1971) J Mater Sci 6:150. doi:10.1007/BF00550346

26. Sutton WH, Feingold (1966) The role of grain boundaries and surfaces in ceramics. Plenum Press, New York

27. Bailey FP, Borbidge WE (1981) Mater Sci Res 14:525

28. Calow CA, Porter IT (1971) J Mater Sci 6:156. doi:10.1007/ BF00550347

29. Vardiman RG (1972) Mater Res Bull 7:699

30. Foley AG, Winters CG (1989) British Ceram Proceed 81(9):2342

31. Baram M, Kaplan WD (2006) J Mater Sci 41(23):7775. doi:10.1007/s10853-006-0897-7

32. Kara-Slimane A, Mbongo B, Tréheux DJ (1999) Adhes Sci Technol 13:35

33. ABAQUS Software (2006) User's manual, version 6.6. Karlsson and Sorensen Inc, Hibbitt

34. Luton MJ, Sellars CM (1969) Acta Met 17:1033

35. Frost HJ, Ashby MF (1982) Deformation mechanism maps, the plasticity and creep of metals and ceramics, 1 edn. Pergamon, Oxford

36. Drillet $P$ (1991) Thèse de doctorat. University of Rennes, France

37. Levi G, Kaplan WD (2006) J Mater Sci 41(3):817. doi:10.1007/ s10853-006-6565-0

38. Dalgleish BJ, Saiz E, Tomsia AP, Cannon RM, Ritchie RO (1994) Scripta Metall Mater 31(8):1109

39. Hattali ML (2009) Caractérisations et modélisations thermomécaniques des assemblages métal/céramique élaborés par thermocompression. Thèse de doctorat, Ecole Centrale de Lyon, France

40. Touloukian YS (1967) Thermophysical properties of high temperature solid materials. MacMillan, New York

41. Haynes International, Inc (2008) http://www.haynesintl.com. Accessed 3 June 2008

42. Lourdin $\mathrm{P}$ (1992) Les liaisons $\mathrm{Ni}-\mathrm{Al}_{2} \mathrm{O}_{3}$ à l'état solide. Etat des contraintes thermique, comportement mécanique. Thèse de doctorat, Ecole Centrale de Lyon, France 